\title{
THE POTENTIAL DEVELOPMENT OF BETAWI CULINARY AS AN ECOTOURISM PRODUCT IN JAKARTA
}

\author{
Dhian Tyas Untari \\ Fakultas Ilmu Pendidikan Pengetahuan Sosial, Universitas Indraprasta PGRI \\ Jalan Nangka No. 58 C (TB. Simatupang), Tanjung Barat, Jagakarsa, Jakarta 12530 \\ tyas_un@yahoo.co.id
}

Received: $4^{\text {th }}$ August 2016/ Revised: $05^{\text {th }}$ December 2016/ Accepted: $13^{\text {th }}$ December 2016

How to Cite: Untari, D. T. (2016). The Potential Development of Betawi Culinary as an Ecotourism Product in Jakarta. Binus Business Review, 7(3), 275-280. http://dx.doi.org/10.21512/bbr.v7i3.1532

\begin{abstract}
The aims of this research were to rebuild the existence of Betawi culinary. The objectives of this research were representing the values of socio-cultural of Betawi culinary, determining the aspects of supply and demand, and developing strategies to improve Betawi culinary potential as an ecotourism products. The research consists method consists of three stages. Those were representation test, market test, and arranging alternatives strategic. The results show that to improve Betawi culinary as the ecotourism products in Jakarta; it can be done with a series of strategies, classified into three classifications. Those are market penetration, market development, and product development. The result is expected to be a reference to the development of Betawi culinary ecotourism as one of the products in Jakarta.
\end{abstract}

Keywords: potential development, Betawi culinary, ecotourism product

\section{INTRODUCTION}

During last ten years, culinary is popular in the community. Not only it is like the basic human needs, but culinary also is the representation of social and cultural (Avenzora, Darusman, Prihatno, \& Untari, 2014). Moreover, Brillat-Savaring defines that culinary is related to history, chemistry, and political economic (Maberly \& Reid, 2014). As the representations and prescriptions of food practices, it perceived habits and attitudes towards food. It represents a certain identity for the readers (Parys, 2013). The popularity of the culinary sectors can be seen from the significant growth in the increase in market share of the food industry of more than 12\% (Bank, 2015) in the restaurant business diners of medium and large scale, which reaches the average of $17 \%$ annually (Parekraf, 2014). The time brought a paradigm shift in society. Through the influence of the environment and the way of life, the individual consciousness is formed which causes a variety of perception or thinking patterns that are ideological where the impact of these brings consumerist society (Meliano \& Budianto, 2004). Moreover, this consumption pattern which is then put in the need to become a culinary reflect the prestige and social status.

Traditional cuisine and environment of society are a unity that can not be separated because the culinary production largely depends on the availability of raw materials provided by the environment. Forests as a source of food for community have the complexity and variety of different physical on land condition (Jenkins, 2008; Saputra, Linda, \& Loviadi, 2015), morphology of land (Jones, Finnan, \& Hodkinson, 2015), and climate (Perry, Rosenzweig, Iglesias, Livermore, \& Fischer, 2004; Simelton et al., 2012). These differences create diversityin crops from each region. The values depicted in the locality of the culinary variety that is consumed by society can be defined as a system of knowledge of local communities or indigenous people that are empirical and pragmatic philosophically. It is empirical because the processed society departs from the facts that happen around their lives. While, it is pragmatic because the whole concept is derived from the results that the thought of knowledge was aiming to solve problems in everyday life.

Food as culinary products becomes an 
indication of the success of sustainable development in a country, where the emphasis on the food needs of the population become one of the indicators. The current interest in local food is explained by issues related to the environment, ethics, sustainability and local health issues. While the consumers desire to support local network and the economy (Nwokorie, 2015) and their wishes to shorten their carbon food print and food chain may also explain the particular behavior (Bjork \& Kaippinen-Raisanen, 2014).

Population as one of the objects of development experience increases the trend to 5,8 billion (Bank, 2013). It also happened in Indonesia where it is projected to increase in population and reach $1,38 \%$ (Bapenas, 2013). FAO data in 2014 showed that the population of Asia is big which created large percentage of consumption (Indonesia > 47\%; Myanmar $>70,1 \%$; Cambodia $>70 \%$; Philippines $>47 \%$; Thailand $>40 \%$; Singapore $>20 \%$ and; Vietnam $>50 \%$ ). While in the United States and Canada with a population of more than 300 million, it has a greater proportion of food consumption value of approximately $15 \%$, and Australia is smaller than 20\% (Untari, 2015). Thus, the culinary business by providing food has a huge opportunity, both in present and future. The entry of the culinary industry into a part of the road map development of creative industries in Indonesia is the government awareness of the magnitude of the economic potential in it. The report of Investor Daily in 2012 saw that sub-culinary sector contributed the largest revenue for the creative industry in Indonesia or approximately $32,2 \%$ of the total contribution of the creative industries to PDB in 2011. The industrial sector is experiencing significant growth, which can be seen from the increasing number of food industry reaching 6,61\% (BPS, 2013), and growth in the restaurant business diners in medium and large scale, which reached an average of $17 \%$ per year with the highest proportion in Jakarta reaching 1361 in 2011. Micro growth in the culinary industry is a chain of activity that is long and wider in the range of activities that accommodate employment like in average, restaurant or diner employing 28 people (Parekraf, 2014). In general, the food industry absorbs labor force to 20-21\% in 2005 to 2011 (Amalia, 2012). With the economic potential of the culinary industry, it provides a wide impact on both micro and macro industry. To maintain the continuity of the culinary industry, it should be directed to the ecological aspects of utilizing and promoting the values of the locality.

Related to the tourism sector, local food may function as a destination trigger, which means traveler may choose a particular destination due to the local food, it serves and for the anticipated culinarygastronomy experience (Bjork \& Kaippinen-Raisanen, 2014). Gastronomy is also acknowledged as an important factor affecting overall tourism experience (Sengel et al., 2015). As society has advanced, the consumption of both food and tourism has changed. In 1950, 25 million tourists took an international holiday. Nowaday, it is over one billion and is forecasted to be risen to 4,2 billion by 2050 optimistically. Food tourism without the doubt is a major component of the tourist it inerary and a focus of destination strategies. The interest in food tourism is a representation of tourism today in which culture has moved out of the museum and is represented in the experience with food tourism one of the central spheres (2016).

One of the areas in Indonesia which have a complexity of the social interaction of high community is Jakarta. There is a gap between the existing market potential with the ability to manage this potential by positioning Betawi culinary market (Avenzora et al., 2014). In the research, it finds that more than half of the variation is known as Betawi culinary and sold continually. Betawi culinary currently gets less attention so that variations of Betawi culinary existing are not entirely known by the public. Based on this background, it is considered to be necessary to focus on the development of Betawi culinary. It is also because Betawi is the forerunner of culture and cultural identity of Jakarta. On the other way, Jakarta is one of most popular destination in Indonesia (The Jakarta Post, 2016). Rural tourists can play an important role in acting as both consumer and "cultural broker" between these networks (Sidali, Kastenholz, \& Bianchi, 2015).

As been mentioned before, the problem in this research is how to manage and optimize the potential of existing Betawi culinary so it can reach the maximum point not only in the present but also for the future. The collaboration of all stakeholders is needed to improve the opportunities and to achieve all programs to develop tourism sector in Jakarta (Guo \& Sun, 2016; Lee, Wall, \& Kovacs, 2015).

Related to the issues that have been described, in general, this research aims to revive the existence of Betawi culinary. Where as in particular, there are several operational objectives in the research. There are making the culinary product which is no longer known to have more popularity in society, delivering culinary products which are little known by the public to the maximum point in its development, and maintaining the existence of culinary products that are already familiar to the public now to be able to survive on position.

\section{METHODS}

The research was conducted Jakarta. The consideration is because Jakarta is the center of government and economy and a major destination for tourists in Indonesia. From the supply side, Jakarta can sufficiently represent the culture including Betawi culinary. Moreover, from the demand side with the high attraction, Jakarta is allowed to become a development of culinary tourism. The research is consisted of three phases, wherein each phase has a different purpose. Thus the methods and samples used also follows the goals of each phase of the study.

In phase 1, after gathering all the information 
which influences the development of ecotourism culinary, the next step is testing the representation. Testing the representation aims to map the Betawi culinary map culture, sortation and determine the position based on the views of some of the community. Therefore, from the testing the representation, researchers get a clear picture of the existence of Betawi culinary. Respondents involved in this phase are non-Betawi people. Betawi community are descended from the five regions of Jakarta with a total of 45 respondents (each 3 people).

In phase 2, the phase is to test the market that aims to see the existence of Betawi culinary. The Objects in the market test are three ceremonial occasions, three formal and three informal restaurants. While the aspect of the market test covers the aspects of demand and supply.

In Phase 3, the method used in the preparation of strategic alternatives is a qualitative method where there are three methods used. There are input method using matrix IFAS/EFAS (Internal-External Strategic Factor Analysis) by compiling key factors like the factors that influence the development of ecotourism culinary internally and externally, adjustment method using matrix Grand Strategy, and SWOT.

\section{RESULTS AND DISCUSSIONS}

Based on the research result, it shows that people awareness of the Betawi culinary is classified into three categories, which are familiar, recall, and unknown. From the 90 types Betawi culinary tested, there are 33 types of cuisine that are in the familiar category, which means that all ninety of the culinary is still well known by all three communities. While 49 types of cuisine are included in the category of recall. By associating with the culinary knowledge of each category, it obtains the following results.

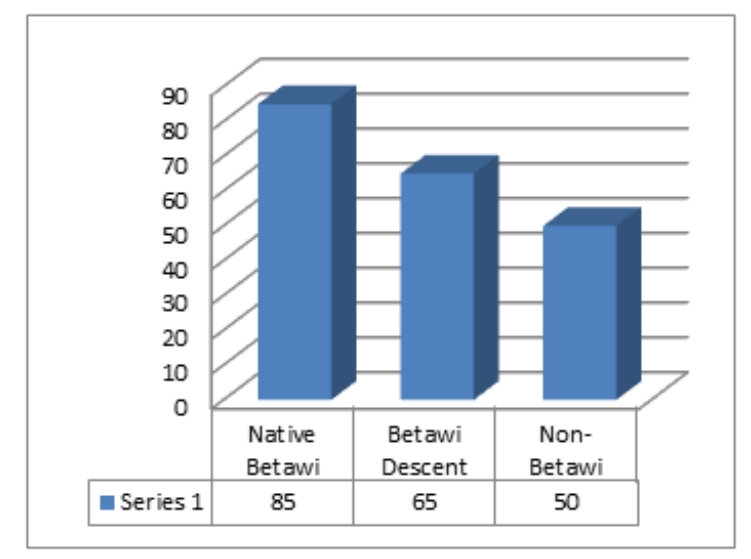

Figure 1 The Classification of Culinary (Source: Data processed, 2016)

According to Figure 1, it shows that the knowledge of the Betawi culinary is most from native Betawi community with an average knowledge of 85 types of cuisine per respondents. While the knowledge of culinary by Betawi descent community is 65 types of cuisine. Moreover, the non-Betawi community only knows 50 types of cuisine, and the unknown culinary to the non-Betawi community is 40 types. This suggests that the dissemination of traditional Betawi culinary to the younger generation of both Betawi people and society, and Betawi people that are not in Jakarta is minimal.

The goal in the second phase is to map and represent the values of uniqueness, authenticity, social, distribution, sensitivity, and seasonality of Betawi culinary based on the ratings from all three communities (Native Betawi, Betawi Descent, and Non-Betawi). Based on the research, the knowledge of socio-cultural values found in Betawi culinary is very diverse; it can be seen in Figure 2.

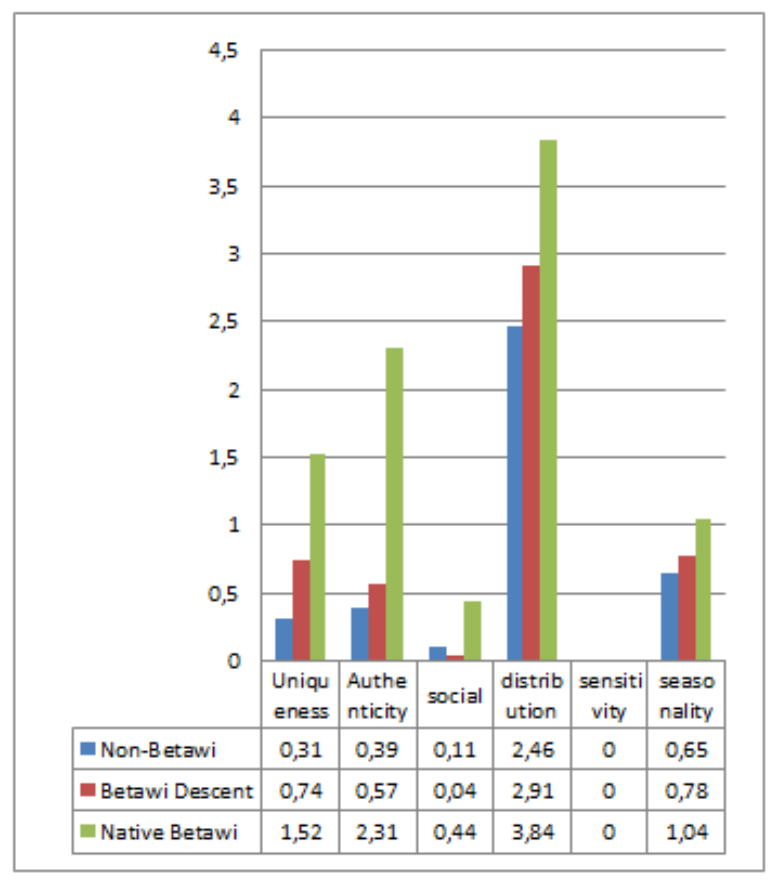

Figure 2 The Knowledge of the Product

(Sources: Data processed, 2016 )

Figure 2 shows that the aspects of the Betawi culinary distribution and seasonality have been degraded, meaning that Betawi descent more than non-Betawi people currently has the problem to find the variation of Betawi culinary. Degradation is also visible in the assessment of the uniqueness and authenticity. It is because some types of Betawi culinary have similarity with other regions that the general public does not give a high appraisal to the aspects of the uniqueness and originality of Betawi culinary.

In the second phase, there is demand and supply analysis performed on 15 restaurants of Betawi culinary which are classified as informal, formal and catering. Table 1 illustrates the result. 
Table 1 The Demand Score

\begin{tabular}{lcc}
\hline & Demand Total Score & Demand Avg Score \\
\hline Informal & 12,4 & 2,48 \\
Formal & 34 & 6,8 \\
Catering & 27 & 5,4 \\
\hline \multicolumn{3}{c}{ (Source: Data processed, 2016) }
\end{tabular}

Table 1 shows that the highest value is the formal restaurant. The values are the formal restaurant service, cleanliness, and availability of support facilities rated much better than in the informal restaurant. Next, handling the catering services at ceremonial events has the second highest bid value. Related to the demand for culinary, here is the consumer profile data. Based on research, it appears that the majority (83\%) of non-Betawi consumers who stay in Jakarta is $32 \%$. The majority is $26-45$ year old. In addition, the male is $53 \%$. From the aspect of income, the majority earns 2-5 million (40\%), has education Diploma-S1 (67\%), and work as an employee. The surprising thing is from consuming motivation of Betawi culinary. The highest motivation is the economic elements meaning that the consumers choose Betawi culinary because the price is relatively low. This may imply that people are willing to pay Betawi culinary cheaply and positioning Betawi culinary as the "cheapest" culinary.

In the last phase of the preparation of strategic alternatives, it is related to the development of the Betawi culinary as the ecotourism products in Jakarta. This strategic formulation tool summarizes and evaluates the strengths and weaknesses of the major function of business area and the foundation by identifying and evaluating the relationship between the areas.

Based on the results of the analysis in Table 2 and 3, it is known that the difference between the weakness and strength is $-0,95$. While the difference between opportunity and threat is $-0,35$. That means the defense strategies that may be applied are market penetration, market development, and product development (strategy of innovation and product diversification) in Betawi culinary.

Referring to the analysis of IFAS and EFAS matrix in Table 2 and 3; it has been arranged in a matrix SWOT to analyze the formulation of alternative strategies namely SO, WO, ST, and WT. The explanation of each strategy is in Table 4.

\section{Table 2 IFA Matrix}

\begin{tabular}{clccc}
\hline No & $\begin{array}{c}\text { The Main Internal } \\
\text { Factors }\end{array}$ & Weight & Rank & Total \\
\cline { 1 - 2 } & \multicolumn{1}{c}{ Strength } & 0,05 & 2 & 0,10 \\
\hline 1 & $\begin{array}{l}\text { The quality of the } \\
\text { production site }\end{array}$ & & & \\
2 & $\begin{array}{l}\text { The quality of storage site } \\
\text { The quality of the } \\
\text { production process }\end{array}$ & 0,05 & 2 & 0,10 \\
& 0,10 & 2 & 0,20 \\
\hline
\end{tabular}

\begin{tabular}{|c|c|c|c|c|}
\hline 4 & $\begin{array}{l}\text { The quality of the sales } \\
\text { process }\end{array}$ & 0,15 & 3 & 0,45 \\
\hline \multirow[t]{3}{*}{5} & $\begin{array}{l}\text { The attractive product } \\
\text { display }\end{array}$ & 0,05 & 4 & 0,20 \\
\hline & Sub Total & 0,40 & & 1,00 \\
\hline & \multicolumn{4}{|l|}{ Weakness } \\
\hline 1 & $\begin{array}{l}\text { The quality of sales } \\
\text { support services }\end{array}$ & 0,15 & 4 & 0,60 \\
\hline 2 & $\begin{array}{l}\text { The quality of Human } \\
\text { Resource }\end{array}$ & 0,10 & 3 & 0,45 \\
\hline 3 & The originality of recipes & 0,15 & 2 & 0,30 \\
\hline 4 & $\begin{array}{l}\text { The promotion as the } \\
\text { medium of information }\end{array}$ & 0,10 & 3 & 0,30 \\
\hline 5 & The availability of capital & 0,10 & 3 & 0,30 \\
\hline \multirow{2}{*}{\multicolumn{2}{|c|}{ Sub Total }} & 0,60 & & 1,95 \\
\hline & & 1.00 & & 2,95 \\
\hline
\end{tabular}

Table 3 EFA Matrix

\begin{tabular}{|c|c|c|c|c|}
\hline No & $\begin{array}{c}\text { The Main External } \\
\text { Factors }\end{array}$ & \multirow{2}{*}{ Weight } & \multirow{2}{*}{ Rank } & \multirow{2}{*}{ Total } \\
\hline \multicolumn{2}{|r|}{ Opportunity } & & & \\
\hline 1 & $\begin{array}{l}\text { The good development of } \\
\text { DKI Jakarta tourist }\end{array}$ & 0,20 & 2 & 0,40 \\
\hline 2 & $\begin{array}{l}\text { The fairly high demand for } \\
\text { traditional culinary }\end{array}$ & 0,10 & 3 & 0,30 \\
\hline 3 & Assistance to UMKM & 0,05 & 2 & 0,10 \\
\hline 4 & $\begin{array}{l}\text { Trend of traditional Betawi } \\
\text { culinary }\end{array}$ & 0,10 & 4 & 0,40 \\
\hline \multirow{2}{*}{\multicolumn{2}{|c|}{$\begin{array}{c}\text { Subtotal } \\
\text { Threat }\end{array}$}} & & & 1,20 \\
\hline & & & & \\
\hline 1 & $\begin{array}{l}\text { Thepublicunderstanding } \\
\text { of the variety of Betawi } \\
\text { culinary }\end{array}$ & 0,05 & 1 & 0.05 \\
\hline 2 & $\begin{array}{l}\text { Nonsuperior culture in DKI } \\
\text { Jakarta }\end{array}$ & 0,05 & 2 & 0,10 \\
\hline 3 & $\begin{array}{l}\text { The heterogeneity of high } \\
\text { culture in DKI Jakarta }\end{array}$ & 0,05 & 2 & 0,10 \\
\hline 4 & $\begin{array}{l}\text { Lessdissemination of the } \\
\text { Betawi culinary knowledge }\end{array}$ & 0,05 & 2 & 0,10 \\
\hline 5 & $\begin{array}{l}\text { The Willingness to pay is } \\
\text { low on Betawi culinary }\end{array}$ & 0,15 & 4 & 0,60 \\
\hline 6 & $\begin{array}{l}\text { The Lack of Betawi } \\
\text { culinary }\end{array}$ & 0,10 & 3 & 0,30 \\
\hline \multirow[t]{3}{*}{7} & $\begin{array}{l}\text { The attitude of people } \\
\text { who choose Betawi xeno } \\
\text { centrism }\end{array}$ & 0,10 & 3 & 0,30 \\
\hline & Sub Total & 0,65 & & 1,55 \\
\hline & Total & 1,00 & & 2,75 \\
\hline
\end{tabular}

The results show that to improve the potential of Betawi culinary as one of the ecotourism products in Jakarta can be done with a series of strategies, which are classified in to three classifications. There market penetration, market development and product development (results of the Cartesian diagram swot analysis). Each classification has alternatives strategies. First, it is market penetration. The alternative strategies are focusing on the existing markets by maximizing the potential internally, utilizing the assistance of 


\begin{tabular}{|c|c|c|}
\hline & $\begin{array}{l}\text { Strength } \\
\text { 1. The quality of the production site } \\
\text { 2. The quality of storage site } \\
\text { 3. The quality of the production process } \\
\text { 4. The quality of the sales process } \\
\text { 5. The attractive product display }\end{array}$ & $\begin{array}{l}\text { Weakness } \\
\text { 1. The quality of sales support } \\
\text { 2. The quality of human resource } \\
\text { 3. The originality of recipes } \\
\text { 4. The promotion as the medium of } \\
\text { information } \\
\text { 5. The availability of capital }\end{array}$ \\
\hline $\begin{array}{l}\text { Opportunity } \\
\text { 1. The good development of DKI } \\
\text { Jakarta tourist } \\
\text { 2. The fairly high demand for } \\
\text { traditional culinary } \\
\text { 3. Assistance to UMKM } \\
\text { 4. Trendof traditional Betawi } \\
\text { culinary }\end{array}$ & $\begin{array}{l}\text { SO } \\
\text { - Focusing on existing markets by } \\
\text { maximizing the potential internally } \\
\text { (S1, S2, S3, S4, S5, O1, O2, O3) } \\
\text { - Utilizing the assistance of relevant } \\
\text { government licensing and legality of } \\
\text { the business (S1, S2, S3, S4, S5, O3) } \\
\text { - Developing new markets by } \\
\text { increasing market segment (S1, S2, } \\
\text { S3, S4, S5, O1, O2, O3) } \\
\text { Making innovation and product } \\
\text { diversification to increase the } \\
\text { quantity of sales (S3, S4, S5, O2, O4) }\end{array}$ & $\begin{array}{l}\text { WO } \\
\text { - Utilizing the help of the } \\
\text { government to improve the } \\
\text { quality of service (W1, O3) } \\
\text { - Improving the networking of } \\
\text { products (W4, O1, O2, O3, O4) } \\
\text { - Working with government and } \\
\text { related shareholder to develop } \\
\text { originality of Betawi culinary } \\
\text { recipes (W3, O1, O2, O3, O4) } \\
\text { - Working with government to } \\
\text { provide training to improve the } \\
\text { quality of human resources }\end{array}$ \\
\hline $\begin{array}{l}\text { Threat } \\
\text { 1. The public understanding of } \\
\text { the variety of Betawi culinary } \\
\text { 2. Nonsuperior culture in DKI } \\
\text { Jakarta } \\
\text { 3. The heterogeneity of high } \\
\text { culture in DKI Jakarta } \\
\text { 4. Less dissemination of the } \\
\text { Betawi culinary knowledge } \\
\text { 5. The willingness to pay is low } \\
\text { on Betawi culinary } \\
\text { 6. The lack of Betawi culinary } \\
\text { 7. The attitude of people who } \\
\text { choose Betawi xeno centrism }\end{array}$ & $\begin{array}{l}\text { TS } \\
\text { - cooperating with the cultural and } \\
\text { Betawi community to deseminate } \\
\text { Betawi culinary so that people can } \\
\text { understand more about the variety of } \\
\text { Betawi culinary (S1, S2, S3, S4, S5, } \\
\text { T1, T4, T7) } \\
\text { - Developing the culinary center on the } \\
\text { strategic areas especially in tourist } \\
\text { spots to develop market of Betawi } \\
\text { culinary (S1, S2, S3, S4, S5, T1, T2, } \\
\text { T4, T6) } \\
\text { Putting Betawi culinary restaurant } \\
\text { in high-class zones to increase the } \\
\text { willingness to pay higher (S1, S2, S3, } \\
\text { S4, S5, T5, T6) }\end{array}$ & $\begin{array}{l}\text { WT } \\
\text { - Maintaining originality of } \\
\text { Betawi culinary that people } \\
\text { understand the values contained } \\
\text { in the Betawi culinary (W3, T1, } \\
\text { T7) }\end{array}$ \\
\hline
\end{tabular}

relevant government licensing and legality of the business, taking advantage of government assistance to improve the quality of service, working together to improve the networking and communication of the product, working with government and related shareholder to develop originality Betawi culinary recipes, cooperating with the government to provide training to improve the quality of human resources, and maintaining the originality of Betawi culinary that people understand the values contained in the Betawi culinary. Second, it is market development. There are utilizing the assistance of relevant government licensing and legality of the business, developing new markets by increasing market segment, capitalizing the government assistance to improve the quality of service, working together to improve networking and communication of the product, working with government and related shareholder to develop originality Betawi culinary recipes, cooperating with the government to provide training to improve the quality of human resources, developing a culinary center in a strategic areas particularly in tourist spots to develop Betawi culinary market, and putting
Betawi culinary restaurants in high class zone to increase the willingness to pay higher. Last, it is product development. The strategies are utilizing the assistance of relevant government licensing and legality of the business, making innovation and product diversification to increase the quantity of sales, taking advantage of government assistance to improve the quality of service, working together to improve networking and communication of the product, and working with government to provide training to improve the quality of human resources.

\section{CONCLUSIONS}

The potential of the traditional Betawi culinary which is owned by Jakarta is very large. On the other hand, the tourism sector in Jakarta is very high because it is one of the largest and most important cities in Indonesia. The development of tourism especially ecotourism in Jakarta needs supports. One of them is a culinary. Therefore, the development of ecotourism and culinary is a very profitable collaboration. The 
government needs to pay more attention to supporting the $\mathrm{d}$ evelopment of ecotourism in Jakarta.

The government can develop the potential of Betawi culinary through market penetration, market development and product development as has been recommended in the research. The result is expected to be a reference in Betawi culinary development as one of the ecotourism products in DKI Jakarta.

\section{REFERENCES}

Amalia, B. (2011). Analisis pengaruh electronic word-ofmouth terhadap keputusan konsumen memilih agen e-ticketing pesawat terbang (Doctoral dissertation). Institut Pertanian Bogor.

Avenzora, R., Darusman, D., Prihatno, J., \& Untari, D. T. (2014). The business potentials of Betawi traditional culinary on traditional culinary ecotourism market in the DKI Jakarta. In Prosiding International Seminar on Tourism Bandung.

Bank, M. (2015). Makanan dan minuman. Industri Update, 2(1).

Bank, W. (2013). The Little Data Book on Africa 2012/2013. Washington: World Bank Publications.

Bapenas. (2013). Proyeksi pertumbuhan penduduk Indonesia. Jakarta.

Björk, P., \& Kauppinen-Räisänen, H. (2014). Culinarygastronomic tourism-a search for local food experiences. Nutrition \& Food Science, 44(4), 294309.

BPS. (2013). Data industri makanan. Jakarta: Badan Pusat Statistik.

Guo, Z., \& Sun, L. (2016). The planning, development and management of tourism: The case of Dangjia, an ancient village in China. Tourism Management, 56, $52-62$.

Jenkins, D. (2008). Review: Agroecology in action: Extending alternative agriculture through social networks by Keith Douglass Warner. Electronic Green Journal, 1(27).

Jones, M. B., Finnan, J., \& Hodkinson, T. R. (2015). Morphological and physiological traits for higher biomass production in perennial rhizomatous grasses grown on marginal land. GCB Bioenergy, $7(2), 375-385$.

Lee, A. H. J., Wall, G., \& Kovacs, J. F. (2015). Creative food clusters and rural development through place branding: Culinary tourism initiatives in Stratford and Muskoka, Ontario, Canada. Journal of Rural Studies, 39, 133-144. http://doi.org/10.1016/j. jrurstud.2015.05.001

Maberly, C., \& Reid, D. (2014). Gastronomy: an approach to study food. Nutrition and Food Science, 44(4), 272-278.
Meliano, V. I., \& Budianto. (2004). Dimensi etis terhadap budaya makan dan dampaknya pada masyarakat. Makara Sosial Humaniora, 8(2), 65-70.

Nwokorie, E. C. (2015). Food tourism in local economic development and national branding in Nigeria. HATMAN Journal of Hospitality and Tourism, 5(1), 21-28.

Parekraf. (2014). Perkembangan usaha restoran/rumah makan berskala menengah dan besar menurut provinsi. Kementrian Pariwisata dan Ekonomi Kreatif.

Parys, N. (2013). Cooking up a culinary identity for Belgium. Gastrolinguistics in two Belgian cookbooks (19th century). Appetite, 71, 218-231. http://doi.org/10.1016/j.appet.2013.08.006

Perry, M., Rosenzweig, C., Iglesias, A., Livermore, M., \& Fischer, G. (2004). Effects of climate change on global food production under SRES emissions and socio-economic scenarios. Elsevire Global Envirinmental Change, 14, 53-67.

Saputra, B., Linda, R., \& Loviadi, I. (2015). Jamur Mikoriza Vesikular Arbuskular (MVA) pada tiga jenis tanah rhizosfer tanaman pisang Nipah (Musa Paradisiacal L.Var.Nipah) Di kabupaten Pontianak. Jurnal Protobiont, 4(1), 160-169.

Sengel, T., Karagoz, A., Cetin, G., Dincer, F. I., Ertugral, S. M., \& Balık, M. (2015). Tourists' approach to local food. Procedia - Social and Behavioral Sciences, 195, 429-437. http://doi.org/10.1016/j. sbspro.2015.06.485

Sidali, K. L., Kastenholz, E., \& Bianchi, R. (2015). Food tourism, niche markets and products in rural tourism: Combining the intimacy model and the experience economy as a rural development strategy. Journal of Sustainable Tourism, 23(8-9), 1179-1197. http:// doi.org/10.1080/09669582.2013.836210

Simelton, E., Fraser, E. D. G., Termansen, M., Benton, T. G., Gosling, S. N., South, A., \& Forster, P. M. (2012). The socioeconomics of food crop production and climate change vulnerability: A global scale quantitative analysis of how grain crops are sensitive to drought. Food Security, 4(2), 163-179. http://doi. org/10.1007/s12571-012-0173-4

The Jakarta Post. (2016). 5 most popular destinations in Indonesia for holiday makers. Retrieved August $30^{\text {th }}, 2016$ from http://www.thejakartapost.com/ travel/2016/05/08/5-most-popular-destinations-inindonesia-for-holidaymakers.html

Untari, D. T. (2015). Strategi pengembangan ekowisata kuliner tradisional Betawi di DKI Jakarta (Proposal Disertasi). Bogor.

Yeoman, I., \& McMahon-Beatte, U. (2016). The future of food tourism. Journal of Tourism Futures, 2(1), 9598. doi:10.1108/jtf-12-2015-0051 